\title{
Causales de extinción de la acción penal y de la ejecución de la pena
}

Víctor Prado Saldarriaga

\section{Concepto y función}

El ejercicio del jus puniendi del Estado se encuentra regulado por diferentes principios que son el resultado de un largo proceso de lucha por la libertad, la democracia y los derechos humanos. Los principios penales de legalidad, lesividad, proporcionalidad y humanidad, entre otros, surgieron en la necesidad de controlar el uso arbitrario y prepotente del control penal por parte del Estado y de sus órganos delegados de poder ${ }^{1}$.

Sin embargo, el proceso de configuración y consolidación de límites y garantías contra el poder punitivo del Estado, conoce también un desarrollo formal no menos significativo a través de las llamadas causales de extinción de la acción penal y de la pena. Se trata de un conjunto de circunstancias diferentes de carácter político, legal, natural o privado, que son ajenas al hecho punible, pero que extinguen su posibilidad de persecusión (acción penal) o de sanción efectiva (ejecución de la pena). Como afirma Cuello Calón: «Las causas de extinción de la responsabilidad penal son determinadas circunstancias que sobrevienen después de la comisión del delito y anulan la acción penal o la pena. Se diferencian de las causas de exención de responsabilidad penal en que estas son anteriores a la ejecución del delito (como la infancia, la locura), o coetáneas, es decir, surgen en el momento de su realización (v.

1 Cfr. Víctor Prado Saldarriaga. Todo sobre el Código Penal. IDEMSA. Tomo I. Lima, 1996, p. 19 y ss. 
gr., la legítima defensa), mientras que las causas de extinción de la responsabilidad penal sobrevienen no sólo después de delito sino aún después que la justicia ha comenzado su persecución y, en ciertos casos, con posterioridad a la sentencia condenatoria». ${ }^{2}$ Precisando más tales diferencias Roy Freyre ha sostenido también que: «la diferencia está en que las causas "extintivas" cancelan una responsabilidad penal que se supone ya surgida o que se tuvo por incuestionable; por tanto, miran al pasado. En cambio las causas "eximentes" impiden el nacimiento de una responsabilidad penal; en consecuencia, tienen en perspectiva el futurom. ${ }^{3}$

Como suele ocurrir en otros ámbitos de la dogmática de las consecuencias jurídicas del delito, la denominación que se otorga a las causales que estamos analizando no es uniforme. Si bien resulta frecuente que se les designe como causales de extinción de la acción penal y de la pena, ${ }^{4}$ también es común detectar que se les denomina causas de extinción de la responsabilidad penal.5 Sin embargo, en la doctrina coexisten otras nomenclaturas como la de condiciones de operatividad de la coerción penal que utiliza Zaffaroni. ${ }^{6}$

En el derecho penal peruano se ha optado por la primera de las denominaciones mencionadas. Es así que tanto en el Código Penal de 1924 (Título XV del Libro Primero) como en el de 1991 (Título V del Libro Primero) el legislador nacional se ha referido a la extinción de la acción penal y de la pena. Sólo en el Código Penal de 1863 el legislador no organizó estas causales bajo una denominación común. ${ }^{7}$

Resulta anecdótico recordar la preocupación que mostraba Cornejo en torno a que las causales que analizamos no podían extinguir la acción penal, por lo que su denominación correcta debería ser causales

2 Cfr. Eugenio Cuello Calón. Derecho Penal. Editora Nacional. México, 1973, p. 626.

3 Luis Eduardo Roy Freyre. Causales de extinción de la acción y de la pena. GRIJLEY. Lima, 1998, p. 21.

4 Cfr. Luis Eduardo Roy Freyre. Ibid.

5 Luis Gracia Martín y otros. Las consecuencias jurídicas del delito en el nuevo Código Penal Español. Tirant Lo Blanch. Valencia, 1996, p. 317.

6 Cfr. Eugenio Raúl Zaffaroni. Manual de Derecho Penal. Parte General. EDIAR. Buenos Aires, 1982, p. 560 y ss.

7 Cfr. Luis Eduardo Roy Freyre. Op. cit., p. 15 y 16. 
de extinción del delito: «la acción no es susceptible de extinción, y que no puede impedirse su ejercicio aun cuando llegare a faltar el fundamento de la pretensión correlativa. Cuando la ley penal o civil habla de la extinción de la acción, entiende referirse, no a la facultad de pretender un derecho, sino a la relación jurídica objeto de la pretensión; o al delito (si se trata de relación personal) pero no como hecho -que históricamente no puede suprimirse- sino como ente jurídico, según la concepción de Carrara. Esto equivale a decir que lo que propiamente se extingue es la relación de que el delito como ente, es elementom. ${ }^{8}$

Cabe señalar, finalmente, que otros sistemas jurídicos nacionales de nuestro hemisferio se han inclinado también por denominaciones similares a la acordada en nuestra legislación peruana. Así, por ejemplo, el Código Penal argentino se refiere a Extinción de Acciones y Penas (Título X del Libro Primero) y el Código Penal colombiano de 1980 trataba De la Extinción de la Acción y de la Pena (Capítulo V, del Título IV del Libro Primero). En cambio el Código Penal mejicano adopta el término Extinción de la Responsabilidad Penal (Título Quinto del Libro Primero), muy semejante, pese a su diferencia cronológica, al que emplea el Código Penal cubano que alude a La Extinción de la Responsabilidad Penal (Título VIII del Libro I).

Ahora bien, según Bustos Ramírez «es mucho más correcto hablar de extinción de la responsabilidad criminal y no de extinción de la responsabilidad penal. Las causas de dicha extinción no están necesariamente vinculadas exclusivamente con el sentido y función de la pena, sino con el sentido y función de la responsabilidad en términos generales, esto es, con el sentido y función del derecho penal. Se trata de dilucidar cuales son los principios que informan el problema de la fundamentación y límites de la intervención penal. Tales principios no son otros que el de la dignidad de la persona, el de los bienes jurídicos y el de la necesidad de la pena.?

8 Angel Gustavo Cornejo. Parte General de Derecho Penal. Tomo Primero. Librería e Imprenta de Domingo Miranda. Lima, 1936, p. 306.

9 Juan Bustos Ramírez. «La Extinción de la Responsabilidad Criminal», en Debate Penal. Año 1. No 3, 1987, p. 367 


\section{Clasificación}

Generalmente los códigos penales contemporáneos incluyen las mismas causales de extinción de la acción penal y de la pena. En ese contexto se advierte que la legislación concede tal condición a la muerte del imputado o reo, a la amnistía, al indulto, a la prescripción y al perdón del ofendido (Cfr. C.P. argentino, Art. 59 ; C.P. colombiano de 1980 , arts. $76^{\circ}$ a $79^{\circ}$; C.P. ecuatoriano, arts. $96^{\circ}$ a $101^{\circ}$ ).

Bustos Ramírez, sin embargo, considera que desde la teoría de la pena "pareciera que en sentido estricto, esto es, desde los contenidos tradicionales de las teorías de la pena, sólo son causas de extinción de la responsabilidad penal, la muerte del reo y el cumplimiento de la condena". ${ }^{10}$

Las causales de extinción pueden clasificarse en razón de varios criterios. La doctrina en este dominio ha planteado varias propuestas que toman en cuenta la efectividad de la causal, su origen o sus alcances.

En relación a su efectividad se diferencia a las causales atendiendo a que ellas proyecten sus efectos únicamente sobre el autor (la muerte del imputado), o que ellos abarquen conjuntamente al autor y a los partícipes del hecho punible (la prescripción).

Luego atendiendo a su origen, las causales se subdividen en aquellas de etiología natural (muerte del imputado), legal (amnistía e indulto) o privada (perdón del ofendido).

$Y$, finalmente, en torno a sus alcances las causales pueden afectar exclusivamente la persecución del delito (extinguen la acción penal) o su sanción punitiva (extinguen la pena).

Roy Freyre, siguiendo a Maggiore y Núñez, ha sistematizado las causales de extinción de una manera idónea y práctica. Para el apreciado jurista sanmarquino es posible una clasificación a partir de dos indicadores. Primero, según el alcance extintivo del jus puniendi. En este ámbito se detectan causales que extinguen la acción penal y la pena como la muerte del reo o la prescripción. Pero también hay causales que sólo extinguen la acción penal como la cosa juzgada o el desistimiento; y causales que únicamente suprimen la pena, caso del indulto o el perdón del ofendido. 
El segundo indicador gira en torno a los responsables que comprende la causal extintiva. Aquí se incorporan causales subjetivas o personales que sólo benefician a los autores o partícipes en quienes se cumplen los presupuestos específicos de la causal: la muerte del imputado o la prescripción. Luego se ubican, también, causales subjetivas que alcanzan a todos los responsables sin atender a sus niveles de intervención en el delito, como la amnistía. Y, por último, se incluyen causales mixtas que reúnen aspectos subjetivos y objetivos como la renuncia del titular del interés ofendido. ${ }^{11}$

\section{Las causales de extinción en el código penal de 1991}

Siguiendo igual sistemática que su antecesor, el Código Penal vigente trata, por separado, a las causales de extinción de la acción penal (Art. $78^{\circ}$ ) y a las causales de extinción de la ejecución de la pena (Art. $85^{\circ}$ ).

\subsection{Causales de extinción de la acción penal}

Se encuentran reguladas en el arrículo $78^{\circ}$ del Código Penal. Estas causales extinguen el derecho de persecución penal del Estado y con él la facultad del Ministerio Público de ejercitar ante la autoridad judicial competente la acción penal. Entendida esta última, como propone San Martín Castro, como «un poder-deber de activar la jurisdicción penal, o sea de pedir al órgano jurisdiccional un pronunciamiento concreto sobre una noticia criminal específica, y que, además, se trata de una iniciativa típicamente procesal dirigida a la activación de la función jurisdiccional para la actuación del derecho penal sustantivo». ${ }^{12}$

El legislador nacional ha considerado las siguientes causales de extinción de la acción penal:
a. La muerte del imputado
b. La prescripción
c. La amnistía
d. El derecho de gracia
e. La autoridad de cosa juzgada

11 Cfr. Luis Eduardo Roy Freyre. Op. cit., pp. 18-19. 


\section{f. El desistimiento \\ g. La transacción}

Cabe señalar que las dos últimas causales sólo son aplicables a los delitos perseguibles por ejercicio privado de la acción penal, como los delitos contra el honor (injuria, difamación o calumnia).

\subsection{Causales de extinción de la ejecución de la pena}

Estas circunstancias suprimen el derecho del Estado de hacer cumplir al condenado la pena que le fue impuesta por una autoridad judicial competente. Sin embargo, alguna de estas causales, como el indulto, operan directamente sobre la ejecución efectiva de la pena, extinguiendo sus períodos regulares de cumplimiento.

Conforme al artículo $85^{\circ}$ del Código Penal son causales de extinción de la ejecución de la pena las siguientes:

a. La muerte del condenado

b. La amnistía

c. El indulto

d. La prescripción

e. El cumplimiento de la pena

f. La exención de la pena

g. El perdón del ofendido

La última de la causales mencionadas tiene también una operatividad condicionada a que la infracción cometida por el sentenciado corresponda a un delito de acción penal privada.

Como se puede apreciar de ambos catálogos, coexisten causales de extinción que poseen una doble función operativa en tanto pueden extinguir la acción como el derecho de ejecución de la pena. En efecto, ello ocurre con la muerte del infractor, con la amnistía y la prescripción.

\subsection{Estudio analítico de las causales de extinción}

Para un mejor análisis de todas las causales de extinción nos referiremos a partir de la siguiente secuencia metodológica: 
Primero revisaremos las causales que afectan tanto a la acción penal como a la ejecución de la pena. En segundo lugar, abordaremos aquellos supuestos que sólo extinguen a la acción penal. Y, en tercer lugar, trataremos de las causas que cancelan únicamente la ejecución de la pena. Aquí también haremos una breve alusión a la naturaleza y función de la rehabilitación.

Finalmente, por su mayor trascendencia práctica, analizaremos de modo individual a la causal de prescripción.

3.3.1 causales de extinción de la acción penal y de la ejecución de la pena

a. La muerte del autor o partícipe del delito. Esta causal obedece a una razón natural y jurídica. La acción penal y la pena tienen su realización en una persona. Conforme a nuestra legislación civil se deja de ser persona con el suceso biológico-social de la muerte (Cfr. Artículo $61^{\circ}$ del Código Civil). Por lo demás, el contenido de la punibilidad y de la punición se orientan a retribuir un mal a una persona, a la cual se le va a privar o restringir determinados bienes jurídicos. $\mathrm{Y}$ desde una perspectiva funcional preventiva, la pena sólo puede promover efectos utilitarios en una persona viva. Como explica Bustos Ramírez «Desde la perspectiva del principio de la dignidad de la persona, el derecho penal aparece con un carácter estrictamente personal e intransferible en su contenido; de ahí que la muerte del reo le signifique al derecho penal la pérdida de su función y sentido. La intervención el Estado más allá de la vida no tiene ninguna legitimación posible». ${ }^{13}$

Resulta relevante la preocupación de Roy Freyre por discutir los efectos de la causal que analizamos ante la llamada muerte clínica y la muerte presunta. Con relación a la primera, estimamos que los efectos funcionales de la pena y el marco legal vigente, permiten, de modo coherente, estimar que ante la declaración de un estado de

12 César San Martín Castro. Derecho Procesal Penal. Volumen I, GRIJLEY. Lima,1999, p. 217.

13 Juan Bustos Ramírez. La extinción de la responsabilidad criminal. Op. cit., p. 367. 
muerte clínica, el derecho del Estado para perseguir o hacer cumplir una pena al autor o partícipe de un delito ha dejado también de existir. Por lo demás, se trata de una situación excepcional que, a nuestro modo de ver, no puede apreciarse exclusivamente en su esfera biológica o en el de sus consecuencias estrictamente civiles, como con acierto y atendibles argumentos postula el maestro sanmarquino. La vida es sobre todo interacción social, capacidad de vincularse con terceros y con el entorno, y la muerte clínica evidencia imposibilidad irreversible de todo ello. Cabría preguntarse si un "descerebrado" puede sentir e interpretar una pena. $Y$ en el caso de que se le condene a muerte biológica, nos preguntamos: ¿cuál sería la oportunidad de su ejecución?, o ¿qué sentido funcional cabría reconocer a dicho proceder punitivo?

Distinta, es la situación de la muerte presunta a la que nuevamente Roy Freyre dedica fundamentada reflexión. En este supuesto compartimos plenamente su opinión, en cuanto siendo la muerte presunta una suposición juris tantum la extinción de la acción penal y de la pena estará sujeta a la eficacia formal de dicha presunción: «nada impide la decisión de tenerse por extinguida la acción penal o la pena de un reo a quien se declaró muerto presunto con motivo, por ejemplo, de un incendio en un centro carcelario o respecto de quien se tiene noticia de haber sido incinerado en el horno de la panadería del penal». ${ }^{14}$

En resumen, pues. desde nuestra posición la muerte biológica, clínica o presunta extinguen la acción o la ejecución de la pena. Ahora bien, no se ha presentado jurisprudencialmente la oportunidad de debatir los casos de muerte clínica o presunta y sus efectos de extinción. La jurisprudencia nacional, sin embargo, exige como medio para acreditar el fallecimiento del imputado o condenado la partida de defunción correspondiente. Es así que en la Ejecutoria Suprema del 16 de setiembre de 1991, recaída en la causa $\mathrm{N}^{\circ} 160-91$ y originaria del Distrito judicial de Huánuco se declaró que «si se ha acreditado con partida de defunción, instrumento público pertinente, la muerte del procesado, resulta procedente declarar la extinción de la acción penal conforme a lo establecido en el inciso 1 del artículo $78^{\circ}$ del Código Penal». Entendemos que en el caso de la 
muerte clínica el documento pertinente para acreditarla será la declaración médica de dicho estado. Luego en la Ejecutoria Suprema del 13 de enero de 1992, emitida en el proceso $N^{\circ} 1271-92$ y procedente de Lima, se sostiene también que «Habiéndose acreditado que el procesado, condenado en primera instancia, falleció durante la tramitación en segunda instancia de un recurso impugnatorio, cabe anular la condena que le fue impuesta y declarar extinguida, por muerte del imputado, la acción penal incoada».

b. La amnistía. Es una causal de origen político. Surge de las decisiones que adopta el Estado frente al tratamiento de determinados delitos, para los cuales estima innecesario mantener la punibilidad o la punición. Por consiguiente es, en esencia, una causal de aplicación coyuntural. Según Bustos Ramírez: «Estimamos que la amnistía y el indulto solo pueden basarse en la necesidad de la pena [...]. En relación a la amnistía, las precisiones sobre la necesidad de la pena requieren de una diferenciación según se trate de determinados delitos cometidos con ocasión de una guerra, o bien de delitos comunes. Para los primeros, la innecesariedad surge fundamentalmente de la idea de la reconciliación social y política. Su persecusión o la aplicación de la pena significarían una perturbación de la paz social, y de la vigencia del ordenamiento jurídico, lo cual entraría en contradicción con el sentido y función del derecho penal. Por tanto, y en atención a la fundamentación de la amnistía, ésta se extiende a la acción penal y a la pena. En cambio, en relación a los delitos comunes, la innecesariedad de la pena sólo puede estar vinculada con transformaciones profundas de la economía y de la sociedad. La alteración de las condiciones que hicieron surgir determinados hechos delictivos deja sin sentido el mantenimiento de la pena. En este sentido la amnistía se convierte en la anticipación de una reforma de derogación de dichos tipos penales. En otros casos no se podría aplicar la amnistía respecto de los delitos comunes y habría que recurrir a la vía del indultom. ${ }^{15}$

La amnistía en nuestra legislación se encuentra regulada por el artículo $89^{\circ}$ del Código Penal que señala que ella «elimina legalmente el hecho punible a que se refiere e implica el perpetuo silencio res-

15 Juan Bustos Ramírez. La extinción de la responsabilidad criminal. Op. cit., pp. 368-369. 
pecto a él». Ella, pues, demanda la promulgación de una ley ordinaria. Esto es, conforme al artículo $102^{\circ}$, inciso $6^{\circ}$ de la Constitución de 1993 es atribución exclusiva del Congreso "ejercer el derecho de amnistía".

La historia de la amnistía en el Perú ha estado ligada a los avatares de la persecución política o al interés de excluir la punibilidad y punición de delitos cometidos por las agencias de seguridad durante la etapa de violencia que vivió el país entre 1980 y 1995. La última amnistía fue promulgada con la Ley $\mathrm{N}^{\circ} 26479$ del 14 de junio de 1995. Ella repercutió fundamentalmente en la condena a efectivos militares por los graves sucesos de la Cantuta. ${ }^{16} \mathrm{Y}$ su aplicación constituyó una de las más flagrantes interferencias del Poder Legislativo en las competencias exclusivas de la administración de justicia.

Ahora bien, en torno a la efectividad y alcances de la amnistía resultan pertinentes las observaciones que formula Roy Freyre: «a) La ley amnistiante debe identificar los hechos delictivos que beneficia mediante la mención de los numerales que los tipifican.

b) La amnistía únicamente aprovecha a los infractores cuyas conductas están comprendidas en el tiempo que precisa la ley.

c) La ley de amnistía comprende a los delitos consumados, no existiendo inconvenientes para que abarque a los continuados y permanentes, siempre que la continuidad o permanencia cesen en el plazo que la norma conceda para este efecto.

d) Si la autoridad encargada de aplicar la ley de amnistía no lo hace con la debida celeridad, o si se niega a hacerle partícipe de su beneficio a quien se cree con tal derecho, entonces procede la acción de hábeas corpus (Art. 12², Inciso 16, de la Ley N ${ }^{\circ} 23506$ ).

e) La Comisión Permanente del Congreso sólo podrá amnistiar en caso que se delegue dicha facultad». ${ }^{17}$

\subsubsection{Causales de extinción de la acción penal}

a) El derecho de gracia. Esta causal es novedosa en nuestra legislación penal. Sus antecedentes los encontramos en la debatida regulación

16 Cfr. Víctor Cubas Villanueva. La Cantuta. Crónica de la Investigación Fiscal. Palestra Editores. Lima,1998, p. 244 y ss.

17 Luis Eduardo Roy Freyre. Op. cit., p. 174 y 175. 
del «indulto de procesados» que tuvo lugar a través del Decreto $\mathrm{Su}$ premo $\mathrm{N}^{\circ} 017-90-J U S$ del 02 de octubre de 1990.

Su fundamento está referido a la necesidad de un juzgamiento que resuelva la situación jurídica del imputado en un tiempo razonable. Sin embargo, lo equívoco de su naturaleza jurídica, así como lo poco ideográfico de su denominación, han generado un justificado desconcierto en la doctrina, al extremo que Roy Freyre le niega la condición de «institución del Derecho", y la asimila a una atípica praxis de corte de secuela del proceso que se aplicó durante el régimen militar de la década de los años setenta. ${ }^{18}$

Conforme al artículo $118^{\circ}$ de la Constitución de 1993, inciso 21 , es atribución del Presidente de la República «[...] Ejercer el derecho de gracia en beneficio de los procesados en los casos en que la etapa de instrucción haya excedido el doble de su plazo más un ampliatorio». Justamente, la exigencia de un plazo de duración exagerado en la investigación judicial del delito, y que opera como presupuesto de su concesión, es lo que diferencia esta causal de la controvertida corte de secuela del proceso.

Por otro lado, su efecto cancelatorio de la acción penal incoada diferencia al derecho de gracia de las previsiones del artículo $137^{\circ}$ del Código Procesal Penal que alude a una excarcelación por el tiempo de detención acumulado. Esta disposición adjetiva sólo posibilita que el imputado sometido a una medida cautelar de detención, pueda cambiar dicha medida por una comparecencia, cuando se han vencido en exceso los plazos ordinarios de la instrucción. ${ }^{19}$

La operatividad de este derecho de gracia está, pues, condicionada a la decisión del Presidente de la República. El cual decide al respecto, luego de evaluar los informes que formulan Comisiones Especiales como la creada por la Ley No 26239 del 27 de junio de 1994.

c. La autoridad de la cosa juzgada. El artículo $90^{\circ}$ del Código Penal declara que «Nadie puede ser perseguido por segunda vez en razón de un hecho punible sobre el cual se falló definitivamentem. De esta manera el legislador nacional ha regulado la garantía procesal del ne bis in idem. La cual, nos vincula con la autoridad de la cosa juzgada.

18 Luis Eduardo Roy Freyre. Ibid., p. 230 y ss.

19 Cfr. César San Martín Castro. Derecho Procesal Penal. Volumen II. Op. cit., pp. 908-909. 
Ahora bien, en el inciso 3 ab initio del artículo $139^{\circ}$ de la Constitución de 1993, y que trata de los principios y derechos de la función jurisdiccional, expresamente se prohibe «revivir procesos fenecidos con resolución ejecutoriada». La doctrina nacional se ha preguntado si tiene igual contenido semántico la expresión «cosa juzgada» que la de «autoridad de la cosa juzgada».

Roy Freyre, siguiendo a Manzini, ha señalado que entre ambas expresiones cabe establecer ligeras diferencias conceptuales. Así la cosa juzgada sería ula esencia de la decisión conclusiva del juicio contenida en una providencia jurisdiccional con carácter de sentencia de absolución o de condena constituida en irrevocable». En cambio, la autoridad de la cosa juzgada sería un efecto, «la fuerza reconocida por la ley a la decisión del juez para regular jurídicamente en forma de relativa inmutabilidad (esto es, fuera de las hipótesis de mutabilidad expresamente previstas por la ley) el caso decidido, de manera que se imponga positivamente con eficacia coercitiva, o sea ejecutiva (llamada actio iudict), y negativamente con eficacia prohibitiva, o sea como preclusión que prohibe la repetición total o parcial del juicio sobre el mismo objeto (excpetio rei iudicati).$^{20}$

Por su parte San Martín Castro, se limita a definir que «la cosa juzgada es un efecto procesal de la sentencia firme, que por elementales razones de seguridad jurídica, impide que lo que en ella se ha resuelto sea atacado dentro del mismo proceso (cosa juzgada formal) o en otro diferente (cosa juzgada material). En este último aspecto el efecto de la cosa juzgada material se manifiesta fuera del proceso penal, y hacia el futuro, impidiendo la existencia de un ulterior enjuiciamiento sobre los mismos hechos". ${ }^{21}$

En consecuencia, pues, la autoridad de cosa juzgada extingue la acción penal incoada en tanto permite advertir que sobre el mismo hecho histórico y su autor se ha emitido ya una sentencia judicial firme. Ahora bien, para que la autoridad de la cosa juzgada ejerza su efecto extintivo, debe evaluarse, previamente, la presencia real de un juzgamiento anterior y en el cual se aprecia una situación de doble identidad con los hechos que se han denunciado y son base del nuevo juicio.

20 Luis Eduardo Roy Freyre. Op. cit., p. 187.

21 César San Martín Castro. Derecho Procesal Penal. Volumen I. Op. cit., p. 276. 
Ahora bien, sólo puede afirmarse la presencia de cosa juzgada si concurren los siguientes requisitos:

a) Identidad del agente o unidad del sujeto imputado en el proceso precedente y en el actual. A ello se denomina límite subjetivo de la cosa juzgada.

b) Identidad del hecho denunciado o unidad del hecho punible en el proceso precedente y con el actual. Este límite objetivo de la cosa juzgada, sin embargo, no implica exigir una identidad en la tipicidad asignada al mismo hecho en ambos procesos. Lo importante es verificar que el hecho ya juzgado sea el mismo que aquél que ahora es sometido a proceso.

En la praxis judicial se han planteado algunas distorsiones, sobretodo en atención a la tipificación distinta que a determinados delitos se asigna en el derecho penal militar. Es así que las lesiones ocasionadas por un efectivo militar o policial en acto relacionado a su función y que implica un abuso de autoridad en el Código de Justicia Militar (Cfr. Art. $81^{\circ}$ Inc. 7 del C.J.M.), no suele admitirse como idéntico al que en el fuero común se aprecia como un delito de lesiones. De esta manera, pues, se privilegia, equivocadamente, la identidad del tipo penal, en desmedro de la exigencia material de identidad del hecho realizado. Frente a esta constatación resulta pertinente la aclaración que formula Roy Freyre al exigir "que el contenido de la notitia criminis narrada en la nueva denuncia debe ser sustancialmente la misma respecto a los hechos expuestos en la sentencia irrecurrible, careciendo de importancia para desvirtuar esta identidad si es que posteriormente se le aderezó con nuevas circunstancias. En el mismo sentido, tampoco la asignación de un diferente nomes juris enerva el requisito eadem res, puesto que un cambio en la designación o identificación jurídica del acontecimiento humano, sin una correspondiente mutación no maliciosa de los hechos, es insuficiente para lograr una nueva acción penal, una nueva sentencia». ${ }^{22}$ La Corte Suprema, por lo demás, ha reconocido la autoridad de la cosa juzgada aún cuando los procesos se han ventilado ante fueros diferentes. Así, por ejemplo, la Ejecutoria Suprema del 25 de octubre de 1996 resolvió que «en cuanto al encausado Esteban Durand 
Tenorio, los hechos materia del juzgamiento son los mismos que han sido conocidos por la zona judicial de la Policía, habiendo recaído en éstos la sentencia de fecha veintiséis de mayo de mil novecientos noventa y cuatro, conforme aparece a fojas mil setecientos catorce, la misma que ha sido confirmada por Resolución del Consejo Superior de fojas mil setecientos dieciséis, fechada el primero de agosto de mil novecientos noventa y cuatro, que ordenó el archivo definitivo de los autos, por resolución de fojas mil setecientos diecisiete, por lo que resulta procedente declarar fundada la excepción de cosa juzgada deducida por el mencionado Esteban Durand Tenorio [...]».

c. Desistimiento y transacción. El Código Penal incluye también causales de extinción que se vinculan con una declaración de voluntad del afectado por el delito, de no incoar o mantener la acción penal, cuando ésta es de ejercicio privado. Estas causales son el desistimiento y la transacción.

Con relación al desistimiento destaca Soler que "consiste en una manifestación de voluntad, por la cual se desiste (el agraviado) de la acción entablada o a entablarse». ${ }^{23}$ Por su parte Peña Cabrera estima que «Si la parte agraviada decide no continuar con el proceso surge la causal de extinción de responsabilidad penal. El ofendido renuncia a la facultad que le otorga el derecho». ${ }^{24}$

La transacción gira en cambio sobre un acuerdo bilateral de voluntades entre la víctima y el autor del delito para concluir, bajo ciertas condiciones, el proceso incoado contra el segundo. Es, pues, un acuerdo conciliatorio entre agraviado y ofensor. Conforme lo definen Bramont Arias y Bramont-Arias Torres se trata de un "convenio por el cual las partes, dando, prometiendo o reteniendo, cada una alguna cosa ponen término a un proceso que ha comenzado. Se trata de una verdadera "composición", cuyo significado jurídico fue el "transigir" en el primitivo Derecho penal». ${ }^{25}$

23 Sebastián Soler. Derecho Penal Argentino. Tomo II. Tipografía Editora Argentina. Buenos Aires, 1956, p. 515.

24 Raúl Peña Cabrera. Tratado de Derecho Penal. Estudio Programático de la Parte General. Segunda Edición. GRIJLEY. Lima, 1995, p. 575.

25 Luis A. Bramont Arias y Luis A. Bramont-Arias Torres. Código Penal anotado. Tercera Edición. Editorial San Marcos. Lima, 2000, p. 300. 
Ahora bien, en la actualidad el espacio disponible para la operatividad de ambas causales de extinción es muy reducido. En efecto, nuestra legislación vigente ofrece un catálogo muy escaso de delitos sujetos al ejercicio privado de la acción penal. Entendiendo a ésta como la persecución del delito por querella directa del agraviado ante la autoridad judicial y sin intervención del Ministerio Público. ${ }^{26}$ Se trata, pues, del ámbito siempre limitado de los «delitos exceptuados». Concretamente sólo encontramos esa posibilidad en los delitos de lesiones culposas leves (Art. $124^{\circ} a b$ initio), contra el honor (Art. $138^{\circ}$ ), contra la intimidad (Art. $158^{\circ}$ ) y contra la reputación industrial (Art. $240^{\circ}$ in fine). No cabe, pues, extender los efectos de extinción del desistimiento y la transacción a otra clase de delitos, ni siquiera a los llamados de acción mixta o a instancia de parte.

El Código de Procedimientos penales regula expresamente en su artículo $325^{\circ}$ la extinción por desistimiento en el juicio por faltas. Y con relación a las querellas el artículo $306^{\circ}$ permite cancelar la acción entablada por transacción, con la conciliación de las partes.

\subsubsection{Causales de extinción de la ejecución de la pena}

a. El indulto. Según el artículo $89^{\circ}$ del Código Penal «el indulto suprime la pena impuesta». Se trata, pues, de una verdadera causal de extinción de la ejecución de una pena concreta. En ese sentido, Soler señalaba que «El indulto es un perdón y extinguir la pena presupone, en consecuencia, una sentencia condenatoria firmem. ${ }^{27}$ Esta causal es también una manifestación especial del llamado derecho de gracia. Ella se manifiesta como una circunstancia extintiva de origen legal y que a diferencia de la amnistía, se proyecta de modo individualizado sobre un condenado, para quien se estima que la pena ha devenido en innecesaria y no podrá alcanzar efecto funcional alguno. ${ }^{28}$

26 Cfr. César San Martín Castro. Derecho Procesal Penal. Volumen II. Op. cit. p. 1014 y ss.

27 Sebastián Soler. Op. cit., p. 521.

28 Sobre las diferencias entre indulto y amnistía véase Luis Eduardo Roy Freyre. Op. cit., p. 237 y 238. 
Sobre su fundamento Bustos Ramírez ha sostenido desde una posición político criminal que con el indulto se pretende «encontrar una solución a la falta de sentido de la pena frente a un caso específico, que pone de manifiesto que el Derecho Penal no podrá cumplir su función protectora de bienes jurídicos ni tampoco servir para la profundización de la capacidad de liberación personal del sujeto. Más bien todo lo contrario. De ahí que la pena aparezca como innecesaria. Nos encontramos frente a la última regla legal no metajurídica, de determinación de la pena que lleva justamente a su no aplicación.

Luego, el indulto solo puede estar referido a la renuncia de la pena y no a la persecución penal, ya que sólo cuando se ha analizado el caso concreto en el proceso se puede llegar a la conclusión que su aplicación contradice el sentido y función del derecho penal.

En segundo lugar, el indulto responde a la idea político criminal de humanizar y concretar en la ejecución de la pena el sentido y función del derecho penal. Es decir, por la forma en que ha transcurrido la ejecución de la pena o bien, por la aparición de nuevos antecedentes que han surgido con posterioridad al proceso en un caso concreto, aparece como contradictorio con el sentido humanizador de la ejecución penal y del sentido y función de la pena, el cumplimiento de éstan. ${ }^{29}$

Conforme a nuestra Constitución Política de 1993, el indulto es una facultad del Poder Ejecutivo y que ejerce el Presidente de la República según se dispone en el inciso 21 del artículo $118^{\circ}$. Operativamente esta facultad se desenvuelve a través del Trabajo de Comisiones del Ministerio de Justicia que analizan los casos de condenados «indultables» para, luego, someterlos a decisión del primer mandatario del Estado.

Ahora bien, en la experiencia reciente de nuestra legislación, el indulto ha sido objeto de varias distorsiones que lo han llevado a convertirse en una medida coyuntural de descongestión de los centros carcelarios. Ha dejado de ser, pues, una opción despenalizadora para convertirse utilitariamente en una nueva llave o vía de «desprisionalización». Pero, además, a través del indulto se ha pre-

29 Juan Bustos Ramírez. La Extinción de la responsabilidad criminal. Op. cit., p. 369. 
tendido superar el grave daño ocasionado a miles de peruanos que fueron injustamente condenados por delitos de terrorismo inexistentes o no probados debidamente. En ese sentido, de manera atípica y polémica, el indulto ha asumido la contradictoria función de suprimir las penas impuestas a personas inocentes. Como señalaba Landrove Díaz «el indultado dejará de cumplir la pena impuesta, o parte de ella, pero técnicamente es un penado». ${ }^{30}$

Por último, en esta etapa de nuestra evolución normativa, el indulto se ha contaminado también de los objetivos efectistas de las normas premiales por colaboración eficaz. En efecto el Decreto Legislativo $\mathrm{N}^{\circ} 824$ incluyó al indulto como un nuevo estímulo para la disociación silenciosa o la delación que coadyuven a la detección y sanción de organizaciones dedicadas al tráfico ilícito de drogas.

El indulto, estima con corrección la doctrina nacional y extranjera, puede ser total o parcial. ${ }^{31}$ Esto es, abarcar toda la amplitud cualitativa y cuantitativa de la pena impuesta o proyectarse únicamente sobre un período, siempre final, de ésta. Es por tanto lógico que «el indulto de la pena principal se extiende a las accesorias». ${ }^{32}$ Sin embargo, el indulto a diferencia de la amnistía, deja intacta la reparación civil fijada a favor de la víctima. Sobre esto último ha precisado Roy Freyre que «el texto penal en comentario nada dice expresamente acerca de la obligación de abonar la reparación civil, pero debe interpretarse que la deja subsistente al señalar el Código Penal en su artículo $89^{\circ}$, como su efecto único, el de "suprimir la pena impuesta”. En cambio el Código de Justicia Militar es más explícito sobre la materia y también más amplio al disponer que "la amnistía y el indulto dejan subsistentes las acciones de la reparación civil", artículo $58^{\circ}$, segundo párrafon. ${ }^{33}$

d. El cumplimiento de la pena. Esta es, si se quiere ser ideográfico, no una causal de extinción de la pena, sino la vía natural del término

30 Gerardo Landrove Díaz. Las consecuencias jurídicas del delito. Segunda Edición. Bosch. Barcelona, 1983, p. 144.

31 Cfr. Juan Bustos Ramírez. La extinción de la responsabilidad criminal. $O p$. cit. p. 370.

32 Borja Mapelli Caffarena y Juan Terradilos Basoco. Las consecuencias jurídicas del delito. Editorial Civitas. Madrid,1996, p. 225.

33 Luis Eduardo Roy Freyre. Op. cit. p. 239. 
de aquella. El cumplimiento de la pena no extingue la sanción, pues sencillamente después del vencimiento total de la pena no queda nada que extinguir. Esta posición es también compartida, para el derecho penal español, por Mapelli Caffarena y Terradillos Basoco: "Es obvio que el derecho subjetivo del Estado a imponer y hacer ejecutar la pena desaparece una vez cumplida ésta. Por ello hubiera resultado aconsejable no aludir al cumplimiento como causa de extinción, puesto que nada extingue» (Borja Mapelli Caffarena Juan Terradillos Basoco. Op. cit, p. 222). En su enfoque particular de las causales de extinción de la responsabilidad criminal, Bustos Ramírez, en cambio, encuentra en el cumplimiento de la condena la realización de las funciones retributiva o preventivas de la pena, lo que justificaría sus facultades extintivas: «La teoría de la retribución tiene como fundamento legítimamente la justicia y la igualdad en relación a las personas; esto es a toda persona sin discriminación de ninguna especie, ha de aplicársele un mal que restablezca el ordenamiento jurídico en la misma magnitud que el mal que quebró ese ordenamiento. Luego, si la magnitud de ese mal impuesto se ha ejecutado plenamente no hay fundamento legítimamente para mantener la responsabilidad criminal. Por su parte, para las teorías generales, sea ésta intimidatoria, o bien positiva, conforme a las nuevas concepciones, en especial de Hassemer y Jakobs, se pueda plantear una posición semejante». ${ }^{34}$

Ahora bien, como precisa Landrove Díaz «la condena debe entenderse cumplida y, por consiguiente, extinguida la responsabilidad penal cuando haya transcurrido el tiempo señalado en la sentencia condenatoria». ${ }^{35}$ Es más, en el caso peruano, el cumplimiento de la sanción impuesta determina la cancelación de los antecedentes penales o lo que nuestra normativa denomina como la «rehabilitación» del condenado (Cfr. artículo 690 del Código Penal). Denominación incorrecta en la medida en que solo una determinada pena inhabilita al sentenciado. No hay, pues, en esta causal el mismo efecto que encontramos en el indulto o en la exención de pena, e

34 Juan Bustos Ramírez. La extinción de la responsabilidad criminal. Op. cit., p. 365 y 366 .

35 Gerardo Landrove Díaz. Op. cit., p. 139. 
incluso en el perdón del ofendido. En todas ellas, a fin de cuentas la pena se extingue porque no se cumple en su totalidad o no se impone. Por otro lado, desde la perspectiva de la necesidad de pena el cumplimiento de la pena no puede ser una causal de extinción en la medida que la realización total de la sanción estaría justificando su necesidad de aplicación o ejecución.

e. El perdón del ofendido. Esta causal tiene un viejo arraigo en el derecho penal nacional y extranjero. Podríamos decir que es un rezago de la etapa inicial de la venganza privada. Landrove Díaz se refiere a ella como a una «modalidad de gracia privada». ${ }^{36}$ Sus orígenes tienen una base idealista cristiana (dar la otra mejilla, perdonar a quienes nos ofenden). No obstante encuentra en la actualidad una nueva justificación basada en la recuperación del espacio de la víctima en la composición del conflicto. Lo cual, entiende Bustos Ramírez, que conlleva riesgos de arbitrariedad: "Ciertamente se podría sostener que es más garantista establecer el perdón del ofendido como causa de extinción de la responsabilidad criminal; pero ello es dudoso, pues equivale a dejar entregada la responsabilidad criminal a la arbitrariedad de una persona, y más aún, como ha sucedido frecuentemente, a que el proceso penal cumpla fines que son ajenos al sentido y función del derecho penal (cual sería la obtención de una indemnización de perjuicios conforme a las miras de la víctima y no al ordenamiento jurídico). Este criterio empalma con una ideología victimológica, en que se pretende garantizar exclusivamente a la víctima, más allá de los ciudadanos en general, lo que equivale que esta forma de extinción criminal quede en una total y absoluta arbitrariedad». ${ }^{37}$

En ese sentido es adecuado exigir que «el perdón ha de ser expreso e incondicionado" como argumentan Mapelli Caffarena y Terradillos Basoco. ${ }^{38}$ Un perdón sujeto a condiciones sería extraño al sentido de la causal a la vez que se convertiría, cuando menos de modo implícito, en una transacción la cual en nuestro sistema legal sólo puede extinguir la acción penal.

36 Gerardo Landrove Díaz. Ibid., p. 145.

37 Juan Bustos Ramírez. La extinción de la responsabilidad criminal. Op. cit., p. 371 .

38 Borja Mapelli Caffarena - Juan Terradillos Basoco. Op. cit., p. 227. 
Frente a la escasa descripción que da la legislación peruana de esta causal resultan atendibles las sugerencias que formula Roy Freyre en torno a su naturaleza y operatividad:

a) «El perdón debe ser otorgado en forma expresa y sin condiciones.

b) Su concesión para uno de los querellados, beneficia a todos;

c) El perdón es irrenunciable por el ofensor; y,

d) Su concesión por uno de los querellantes no perjudica el derecho de los otros: en consecuencia, en tal caso no se extingue la pena hasta que todos los ofendidos perdonen». ${ }^{39}$

El Código Penal peruano regula esta causal en el inciso $4^{\circ}$ del artículo $85^{\circ}$ y se alude nuevamente a un uso condicionado de la misma. Ella sólo operaría en el caso de delitos de acción penal privada. Ahora bien, por su naturaleza estos delitos son sancionados con penas privativas de libertad de corta duración y de multa, de allí que el efecto real del perdón del ofendido en nuestra legislación sea muy relativo. Tradicionalmente esta causal fue considerada en los delitos contra la libertad sexual y en el delito de adulterio que regulaba el Código Penal de 1924 (Art. 213\%). Sin embargo, estos supuestos ya no existen en la legislación vigente.

d. La exención de pena. Nuevamente el legislador peruano utiliza esta equívoca denominación en el artículo $85^{\circ}$ inciso 3 . En esta ocasión lo hace para referirse a una causa de extinción de la pena, pero cuya eficacia no se proyecta sobre la ejecución de la sanción sino exclusivamente sobre su imposición. En realidad se alude, pues, a una institución diferente a la que regula el artículo $68^{\circ}$ del Código Penal. ${ }^{40} \mathrm{Y}$ tampoco aquí nos encontramos regulando aquellos supuestos que cancelan la pena como premio a los delincuentes que participan de un procedimiento de colaboración eficaz, y a los cuales nuestro legislador identifica también como casos de exclusión de pena. ${ }^{41}$

39 Luis Eduardo Roy Freyre. Op. cit., p. 248.

40 Cfr. Cesar San Martín Castro. Derecho Procesal Penal. Volumen II. Op. cit., p. 1102.

41 Cfr. Decreto Legislativo $N^{\circ} 815$, Art. $1^{\circ}$. 
Como causal de extinción de la pena el legislador nos vincula, más bien, con las llamadas «excusas absolutorias o causales personales de exclusión de pena». Como señala Zaffaroni: «se trata de causas personales que excluyen sólo la penalidad de la conducta y que se establecen por puras consideraciones político-penales». ${ }^{42}$

El Código vigente incluye excusas absolutorias en dos casos:

a) En los delitos contra el patrimonio cuyos sujetos se encuentran estrechamente vinculados, tal como se regula en el artículo $208^{\circ}$ del Código Penal.

b) En los delitos de encubrimiento real y personal que ejecuta el agente por sus relaciones estrechas con el autor de los mismos, tal como se dispone en el artículo $406^{\circ}$ del Código Penal.

De lo que eximen estas causales es de la imposición de la pena. En términos más precisos se exime de la pena concreta, pues ella no llega a definirse ni evaluarse judicialmente.

Ahora bien, como hemos mencionado en ocasiones anteriores, la exención de pena que menciona el artículo $299^{\circ}$ en los casos de posesión de drogas en escasa cantidad y para consumo personal no es tal. ${ }^{43}$ Fundamentalmente porque la exención presupone una persona culpable y esto último tiene como presupuesto la ejecución de un injusto por el imputado. No siendo típica la posesión de drogas para el consumo personal, no es posible declarar culpable a su autor, ni mucho menos poder aplicarle una pena.

\subsubsection{Otras causales de extinción}

El Código Penal y la legislación penal complementaria y especial han incorporado varias instituciones que tienen también efectos cancelatorios sobre la acción penal y la penalidad. El supuesto más generalizado, en los últimos tiempos, es el que deriva de los procedimientos especiales de colaboración eficaz o lo que se ha denominado también el derecho penal premial o el derecho penal de recompensas.

42 Eugenio Raúl Zaffaroni. Manual de Derecho Penal. Op. cit. p. 560.

43 Cfr. Víctor Prado Saldarriaga. Todo sobre el Código Penal. Op. cit., p. 178. 
Efectivamente, a partir de la experiencia de la legislación contra el terrorismo, el legislador nacional viene promoviendo la aplicación de efectos de extinción de la acción penal o de la ejecución de la pena, en el caso de delincuentes que se arrepienten de su actividad ilícita y colaboraran con las autoridades del sistema de control penal para la prevención y sanción de la criminalidad grave y organizada. ${ }^{44}$

Cabe recordar que el Código Penal contiene también supuestos premiales que se vinculan con un arrepentimiento posterior al delito, y que permiten la exención de la pena. Ello ocurre en el caso del delito de falsedad en juicio (Arr. 158 ) y en los delitos de rebelión, sedición y motín (Art. 351\%).

La diferencia entre estos supuestos de exención y los que se regulan como causales extintivas conforme al artículo $85^{\circ}$ inciso 3 del Código Penal, es que los primeros como en el caso del artículo $68^{\circ}$ son facultativos y su aplicación depende de una decisión judicial. En cambio en los segundos la causal extintiva surge directamente por mandato imperativo de la ley.

\subsubsection{La rehabilitación}

Sostiene Jescheck que la rehabilitación permite «restablecer jurídicamente el prestigio social de un condenado dentro de la comunidad». ${ }^{45}$ Velásquez Velásquez, de modo análogo, menciona que ella consiste en «la restitución del condenado al status jurídico en que se encontraba antes de proferirse la sentenciam. ${ }^{46}$

Con la rehabilitación se deben, pues, eliminar los efectos penales de iure que afectan al sentenciado y que, como señalan Cobo del Rosal y Vives Antón, son distintos de las penas y medidas de seguridad. Según estos autores entre tales efectos se pueden considerar a «la imposibilidad de obtener la condena condicional si se comete otro delito, la posibilidad de que se aplique la agravación por reincidencia o de que

44 Cfr. Decretos Legislativos $N^{\circ} 815, N^{\circ} 824, N^{\circ} 901$ y No 902; César San Martín Castro. Volumen II. Op. cit., p. 1036 y ss.

45 Hans-Heinrich Jescheck. Tratado de Derecho Penal. Volumen Segundo. Bosch. Barcelona, 1981, p. 1247.

46 Cfr. Fernando Velásquez Velásquez. Derecho Penal. Editorial Temis. Bogotá, 1994, p. 654. 
se califique al autor como habitual, la incapacidad para participar en determinados concursos públicos o ejercer ciertas profesiones, así como toda una serie de restricciones en orden al ejercicio de actividades que necesiten permiso o licencia de algún organismo públicom. ${ }^{47}$

Se trata, pues, de un medio legal que anula los efectos penales de la sentencia condenatoria en la persona del sentenciado. Ahora bien, opera luego de cumplida o extinguida la sanción impuesta. Por tanto, la rehabilitación no anula la pena (ésta ya se cumplió o extinguió) sino la condena. En términos más específicos, con la rehabilitación se elimina la condición de condenado en aquel que cumplió una pena.

Desde una perspectiva evolutiva, la rehabilitación ha transitado por tres etapas. Primero se le identificó como una reposición del ejercicio de los derechos que le fueron suspendidos al autor o partícipe de un hecho punible a través de una sentencia condenatoria, y más precisamente por la imposición de una pena de inhabilitación. Posteriormente, fue entendida como la cancelación de los antecedentes o registros oficiales de las condenas impuestas a un sentenciado. Y, finalmente, en su actual concepción, la rehabilitación ha integrado ambos conceptos funcionales. Esto es, con la rehabilitación se habilita al inhabilitado y se anulan los antecedentes penales del penado que surgieron con la inscripción de su condena en los registros correspondientes. ${ }^{48}$ El Código Penal peruano de 1924, por ejemplo, asignó a la rehabilitación ambas funciones (Cfr. arts. $130^{\circ}$ y $131^{\circ}$ ). Sin embargo, en el Código de Procedimientos Penales de 1940 el legislador nacional sólo trató de la rehabilitación como cancelación de antecedentes penales (Cfr. arts. $343^{\circ}$ y $344^{\circ}$ ).

Se ha debatido constantemente en torno a la naturaleza sustantiva o procesal de esta institución. Sin embargo, en la actualidad se admite que la rehabilitación es una institución mixta, pues en su esfera normativa corresponde al derecho penal, pero como realización de un derecho subjetivo del sentenciado demanda de una vía procedimental para su reconocimiento. ${ }^{49}$

El Código Penal de 1991 regula la rehabilitación en los artículos $69^{\circ}$ y $70^{\circ}$ los cuales fueron, en parte, inspirados por el Código Penal Tipo para Latinoamérica (Cfr. arts. $87^{\circ}, 88^{\circ}$ y $90^{\circ}$ ).

47 Cfr. M. Cobo del Rosal - T. S. Vives Antón. Derecho Penal. Parte General. Segunda Edición. Tirant lo Blanch. Valencia, 1987, p. 726.

48 Cfr. M. Cobo del Rosal - T. S. Vives Antón. Op. cit., p. 725.

49 Cfr. Luis A. Bramont Arias y Luis A. Bramont-Arias Torres. Op. cit., p. 264. 
La rehabilitación en la legislación vigente se extiende a penas y medidas de seguridad. Sus efectos abarcan la restitución en el ejercicio de los derechos suspendidos con la condena, así como la cancelación de antecedentes penales. Sin embargo, ella no puede reponer en los cargos o funciones que le fueron suprimidos al condenado.

Ahora bien, el cambio más importante que produjo la reforma penal fue la eliminación, para la procedencia de la rehabilitación, de todo plazo posterior al cumplimiento o extinción de la sanción impuesta. En el Código vigente, pues, la rehabilitación opera desde el preciso momento en que se cumple la pena o medida de seguridad, o cuando éstas son suprimidas por alguna causal de extinción como el indulto, la amnistía o la prescripción. Al respecto, el artículo $69^{\circ}$ ab initio señala, expresamente: "El que ha cumplido la pena o medida de seguridad que le fue impuesta, o que de otro modo ha extinguido su responsabilidad, queda rehabilitado sin más trámite».

Otra innovación positiva fue la prohibición de comunicar a cualquier entidad o persona, con posterioridad a la rehabilitación, ningún registro o antecedente vinculado a la condena anteriormente impuesta. Esta obligación de silencio y confidencialidad es imperativa y resulta funcional al objetivo de la rehabilitación el cual no es otro que eliminar para siempre y ante la colectividad todo indicio o rezago de «marca penalm. ${ }^{50}$

En un plano jurisprudencial la rehabilitación no ha producido controversias relevantes. En todo caso, las principales dudas que se han planteado en la judicatura han girado en torno a su aplicación en casos de incumplimiento de penas de multa impuestas conjuntamente con penas privativas de libertad, o ante el no pago de la reparación civil fijada en la sentencia.

Con relación a lo primero se ha resuelto acertadamente negando la rehabilitación, puesto que la misma sólo puede operar si se cumplieron todas las penas impuestas. En ese sentido en la Ejecutoria Superior del 10 de agosto de 1995, recaída en la causa $N^{\circ}$ 163-92 de la Décimo Segunda Sala Penal de la Corte Superior de Lima, se precisó que «si al sentenciado se le impuso conjuntamente con una pena privativa de libertad una pena de multa, la cual no tiene la condición de sanción

50 Cfr. Hans-Heinrich Jescheck. Tratado de Derecho Penal. Volumen Segundo. Op. cit., p. 1252. 
accesoria sino de principal, la rehabilitación no es procedente mientras no se haya pagado dicha pena pecuniaria».

$Y$ en cuanto a lo segundo se ha decidido, también con corrección, que el incumplimiento del pago de la reparación civil no obstaculiza ni impide la rehabilitación. Al respecto una Ejecutoria Superior del Primer Tribunal Correccional de Lima, citada por Villavicencio Terreros, ${ }^{51}$ y emitida en el expediente $\mathrm{N}^{\circ}$ 68-84 declaró que «siendo la exigencia del pago de la reparación civil, de carácter civil, no constituye un requisito para la rehabilitación del sentenciado".

En realidad, el problema central de la rehabilitación en el Perú es que no se concede de oficio, pese a que a ello apunta el sentido de la ley vigente. Esto significa que en nuestro medio se puede seguir «condenado" pese a que se haya cumplido la sanción impuesta en la sentencia. Ello también ocurre en los casos donde se impuso una suspensión de la ejecución de la pena y el plazo de prueba se venció exitosamente (Art. $61^{\circ}$ ). Es, pues, necesario agotar los esfuerzos administrativos pertinentes para revertir esta endémica situación de inercia judicial frente a la rehabilitación y el derecho del sentenciado que cumple los requisitos del artículo $69^{\circ}$ a quedar "rehabilitado sin más trámite».

\section{La prescripción}

\subsection{Concepto y fundamentación}

De manera concreta la prescripción puede definirse como el transcurso del tiempo que extingue la persecución de un delito o la ejecución de una pena. No obstante, en un plano más técnico se identifica a la prescripción como la pérdida, por parte del Estado, de la facultad de ejercitar en un caso concreto el jus puniendi. En ese sentido, por ejemplo, Rodríguez Devesa precisa que la prescripción viene a ser «la extinción por el transcurso del tiempo del derecho del Estado a imponer o hacer ejecutar la pena ya impuestam. ${ }^{52}$

51 Felipe Villavicencio Terreros. Código Penal. Cultural Cuzco. Lima, 1990, p. 240.

52 José María Rodríguez Devesa. Derecho Penal Español. Parte General. Décima Edición. Dykynson. Madrid, 1986, p. 681. 
Otros conceptos de prescripción aluden más bien a los efectos que aquella produce sobre la antijuricidad de un hecho punible y sobre la culpabilidad o responsabilidad de su autor. Señalándose que aquella tendría la condición de circunstancia que invalida el delito y sus consecuencias. Al respecto, Del Toro Marzal, sostiene que la prescripción «supone la invalidación por el transcurso del tiempo de la valoración penal de aquellas acciones y omisiones que, hallándose penadas por la ley, comparecen en la realidad social y jurídicam. ${ }^{53}$

Rey Gonzáles, luego de evaluar los distintos criterios de fundamentación de la prescripción que se han sustentado en la doctrina y jurisprudencia, a lo largo del tiempo, destaca que en el presente ella encuentra su sustento en «los principios constitucionales de presunción de inocencia, prohibición de indefensión y derecho a un juicio sin dilaciones indebidas, todos ellos conectados con el principio de seguridad jurídica». ${ }^{54}$ Por su parte Bustos Ramírez asocia el fundamento de la prescripción a la necesidad de pena, ya que «después de pasado un determinado tiempo se estima innecesaria la pena, no sólo por razones de tipo preventivo-general o especial, sino también en virtud del concepto mismo de necesidad de la pena». ${ }^{5}$ A ello, Morillas Cueva agrega que: «el Estado, ante poderosas razones de política criminal y utilidad social basadas todas ellas en los efectos que produce el paso del tiempo y entre los que pueden incluirse la mayoría de los enunciados con anterioridad que van desde la disminución del interés represivo, la extinción de los efectos antijurídicos del hecho y de la alarma social producida, las dificultades probatorias hasta la eliminación de un estado de incertidumbre en las relaciones jurídicas entre el delincuente y el Estado, renuncia al ejercitar el ius puniendi que le corresponde al declarar extinguida la responsabilidad penal». ${ }^{56}$ Por consiguiente, no cabe duda que el fundamento esencial de la prescripción responde a una

53 Cfr. Juan Córdova Roda y otros. Comentarios al Código Penal. Tomo II, Barcelona, 1972, p. 668.

54 Cfr. Carlos Rey Gonzales. La prescripción de la infracción penal en el Código de 1995. Marcial Pons. Madrid, 1999, p. 43 y ss.

55 Juan Bustos Ramírez. Manual de Derecho Penal Español. Parte General. Ariel. Barcelona, 1984, p. 460.

56 Lorenzo Morillas Cueva. Teoría de las consecuencias jurídicas del delito. Editorial Tecnos. Madrid, 1991, p. 197. 
necesidad político criminal de controlar el ius puniendi a partir de su ejercicio temporal razonable y a favor de la seguridad jurídica de los ciudadanos.

\subsection{Legislación nacional}

Tradicionalmente en nuestro país, el legislador ha elaborado un sistema normativo sobre la prescripción, en el cual se han diferenciado los plazos de extinción en función de la naturaleza de las penas conminadas y de su duración legal. Ese fue, por ejemplo, el criterio que predominó en el Código Penal de 1924 y que era coherente con la pluralidad de tipos de penas privativas de libertad que en él coexistían (Cfr. arts. $119^{\circ}$ y ss.).

En el Código Penal de 1991 se ha establecido un régimen legal novedoso. Como regla general se señala que para la determinación del plazo de prescripción de la acción penal o de la ejecución de la pena, debe atenderse al límite máximo de pena privativa de libertad conminada en la ley para el delito cometido. Esto es, dicho límite máximo de pena legal será el término del plazo de la prescripción ordinaria. Sin embargo, el legislador ha establecido que el plazo de prescripción no será superior, en ningún caso, a los veinte años.

Ahora bien, tratándose de penas conminadas no privativas de libertad (multas, limitativas de derechos, restrictivas de la libertad), conjuntas o alternativas, el plazo ordinario de prescripción será de tres años.

En el caso de penas de duración indeterminada como la cadena perpetua, la ley establece un plazo legal de prescripción ordinaria de treinta años.

Los artículos $80^{\circ}$ y $86^{\circ}$ del Código Penal tratan de los plazos de prescripción que hemos mencionado. Cabe anotar que dichas disposiciones asumen criterios similares a los acordados durante el proceso de elaboración del denominado Código Penal Tipo para Latinoamérica (Cfr. Art. $102^{\circ}$, Incs. 2 y 3).

La llamada prescripción extraordinaria, consecuencia de la concurrencia de causales de interrupción de la prescripción y que se define en los artículos $83^{\circ}$ y $87^{\circ}$ del Código Penal, mantiene el mismo requerimiento que se adoptó durante la vigencia del Código Penal derogado. En efecto, la ley precisa que la prescripción extraordinaria opera al cumplirse cronológicamente el plazo de prescripción ordinario más la 
adición de la mitad de dicho plazo. Esto supone que si la pena conminada para el delito de estafa es de seis años (Art. 196) como máximo, lo que sería el límite del plazo de prescripción ordinaria para dicho delito, la prescripción extraordinaria se cumpliría al transcurrir un total de nueve años.

En el caso de delitos cuyas penas conminadas sean multa, inhabilitación, prestación de servicios a la comunidad, limitación de días libres, expatriación o expulsión de extranjeros, la prescripción extraordinaria operaría transcurridos cuatro años y seis meses. Esto último en atención a que, como se mencionó, el plazo de prescripción ordinario en tales casos es de tres años.

\section{La prescripción en el Derecho Penal}

La prescripción es la pérdida por el transcurso del tiempo del derecho del Estado a perseguir o sancionar penalmente al autor o partícipe de un delito. La prescripción puede ser ordinaria o extraordinaria. Las reglas sobre la prescripción se encuentran contenidas entre los artículos $80^{\circ}$ a $88^{\circ}$ del Código penal.

El artículo $84^{\circ}$ se refiere al supuesto de suspensión de la prescripción. La norma mencionada solo se aplica a los plazos de prescripción de la acción penal. En ella se precisa que se suspende la prescripción de la acción penal cuando excepcionalmente el proceso penal a incoar o ya incoado, por el delito imputado queda supeditado a lo que se resuelva en una vía extrapenal. Es el caso, por ejemplo, de las cuestiones prejudiciales. ${ }^{57}$ En caso de suspensión los plazos ordinario o extraordinario no corren mientras subsista la causal que determinó dicho efecto.

Cabe señalar que el Código vigente estipula en su artículo $88^{\circ}$ que ante la pluralidad de agentes, los plazos de prescripción se aprecian y contabilizan de modo individualizado. Por su parte el artículo $91^{\circ}$ declara

57 Cfr. Florencio Mixán Mass. Cuestión Previa, Cuestión prejudicial, excepciones en el procedimiento penal. Ediciones BLG. Trujillo, 1999, p. 122 y ss. 
expresamente que el imputado tiene el derecho de renunciar a la prescripción de la acción penal. Esta disposición que implica un reconocimiento de la primacía constitucional de la presunción de inocencia, contradice radicalmente la posición que asumió sobre el particular el Código de 1924 (Art. 129 "La prescripción es irrenunciable»).

Ahora bien, la coherencia original del marco legal de la prescripción de la acción penal se vio alterada como consecuencia de un suceso político que repercutió en el Derecho penal. En efecto, la finalidad de evitar la superación por el paso del tiempo de los cargos formulados contra un ex - Presidente de la República, determinaron que el Congreso decidiera la promulgación de la controvertida Ley No 26641 que configuró como delito la situación procesal de contumacia e incorporó confusas fórmulas de suspensión e interrupción de la prescripción de la acción penal para tales casos. Sobre esta norma de excepción, es esclarecedora la reflexión crítica que en torno a ella ha formulado Roy Freyre: «Pensamos que es una arbitrariedad, disfrazada con ropaje jurídico, conminar de la manera indicada a que un ciudadano, presumiblemente inocente según norma constitucional (Art. $2^{\circ}$, Inciso 24, apartado "e"), soporte sumisamente la eventualidad de una condena a pena privativa de libertad, y en caso de rehusarse a comparecer, considerarlo como autor de un insólito delito de contumacia, aparte de agravar su situación jurídica al quedar en suspenso la prescripción del delito primigenio que motiva su alejamiento del proceso. Resulta, así, que un mismo hecho consistente en que el agente se sustrae a la acción de la justicia, con el complemento se le "declare contumaz", genera dos graves consecuencias jurídico-penales: la comisión de un nuevo delito y la suspensión de la prescripción de la acción penal.

Es un principio propio del Derecho natural reconocerle a la persona que se sabe perseguida por la justicia, la posibilidad de eludir su detención y juzgamiento valiéndose de un medio tan elemental y a su alcance como es el sustraerse a "la acción de la justicia", sin que tal decisión haga suponer al menos su responsabilidad en los hechos investigados". ${ }^{58}$

Esta norma no sólo distorsiona los criterios imperantes en la legislación nacional e internacional de la materia, sino que, además, hace visible lo negativo y arbitrario que se vuelve el Derecho penal cuando se le utiliza como un medio de persecución política.

58 Luis Eduardo Roy Freyre. Op. cit., p. 106 y 107. 


\subsection{Reglas especiales}

El Código Penal de 1991 contempla también normas especiales de prescripción de la acción penal. Ello ocurre en los supuestos siguientes:

a. Cuando existe un concurso de delitos.

b. Cuando el autor o partícipe del hecho punible al momento de comisión del delito tenía más de 18 años y menos de 21 años de edad, o más de 65 años de edad.

c. Cuando se sanciona el delito con penas conminadas alternativas o conjuntas.

d. Cuando el autor de un delito contra el patrimonio del Estado, tenía la condición de funcionario o servidor público.

e. Cuando la infracción cometida es una falta.

Con relación al primero de los supuestos mencionados, esto es, cuando media un concurso de delitos, el legislador ha diferenciado en el artículo $80^{\circ}$ los plazos de prescripción aplicables en un concurso ideal de delitos (Art. $48^{\circ}$ C. P.), y en un concurso real de delitos (Art. $50^{\circ}$ C. P.).

En el caso de un concurso ideal el plazo de prescripción se contabiliza en función de las penas conminadas para el delito más grave. Se aplica, pues, un criterio similar al de absorción, que rige para la definición y determinación de la pena en este tipo de concursos.

Tratándose de un concurso real, la regla es que el plazo de prescripción debe apreciarse de modo independiente para cada uno de los delitos en concurso. Esto es, contando por separado los términos que corresponden a las penas conminadas para cada delito. Es claro que esta disposición no tiene efectos prácticos ante un concurso real homogéneo, por tratarse del mismo tipo de delito y por ende del mismo tipo de pena.

En atención a la edad del agente, lo temprano y avanzado de la misma, en los niveles etáreos que fija el artículo $81^{\circ}$ del Código penal, determinan que el plazo de prescripción ordinario y extraordinario aplicables al delito cometido se reduzcan a la mitad. Para lo cual, claro está, la edad del agente al momento de comisión del delito debe acreditarse de modo suficiente, $y$ con los documentos pertinentes para ello (Partida de Nacimiento, Libreta Militar, Libreta Electoral, Docu- 
mento Nacional de Identidad, etc.). Cabe anotar que el artículo $81^{\circ}$ alude de modo genérico al plazo de prescripción, sin diferenciar entre prescripción de la acción penal y prescripción de la pena. En consecuencia, estimamos que la reducción prevista es también aplicable para efectos de la prescripción de la sanción. Lo cual, por lo demás, resulta coherente con lo establecido en el artículo $86^{\circ}$ del Código Penal que establece que: «El plazo de prescripción de la pena es el mismo que alude o fija la ley para la prescripción de la acción penal».

Merece especial atención el caso en el cual la ley penal fija para un delito penas conminadas alternativas o conjuntas. Por ejemplo, pena privativa de libertad o prestación de servicios a la comunidad, tal como ocurre en el delito de autoaborto que tipifica y sanciona el artículo $114^{\circ}$ del Código Penal. O cuando se trata de pena privativa de libertad y multa como se observa en el artículo $194^{\circ}$ que se refiere a la receptación. Ante la ausencia de norma expresa que de pautas al respecto, somos de la opinión que en estos casos la prescripción de la acción penal deberá contabilizarse en función de las dos o más penas alternativas o conjuntas que el legislador fija para la sanción de un mismo delito.

En consecuencia, pues, la extinción de la acción penal por prescripción ordinaria o extraordinaria, sólo será posible cuando se hayan vencido, paralela o secuencialmente, los diferentes plazos de prescripción que correspondan a todas las penas alternativas o conjuntas. En tal sentido, no estimamos correcto considerar la prescripción solamente en atención a los plazos de las penas privativas de libertad. Sobre esto último hay que recordar que las penas no privativas de libertad no son más benignas que aquellas, sólo se trata de penas de distinta naturaleza.

Tampoco consideramos legal entender que frente a sanciones alternativas, la exclusión de una o más de tales penas se produce a través de la acusación fiscal. Sobre esto último cabe recordar que la pena que el Fiscal solicita en su acusación escrita u oral, es solamente una pretensión punitiva y no un acto de determinación de la pena, tarea que, como bien lo expresa el artículo $46^{\circ}$ del Código Penal, es de absoluta competencia del órgano jurisdiccional, el cual la ejerce exclusivamente en el momento de la sentencia. Sólo en ese instante se decide cuál de las penas alternativas se aplicará al condenado.

Ahora bien, el hecho que el tiempo transcurrido desde la comisión del delito alcance el plazo de prescripción de la pena privativa de liber- 
tad que concurre como sanción alternativa con una pena no privativa de libertad, cuyo plazo de prescripción no ha vencido, no inhabilita al juzgador a decidir en la sentencia la imposición de una pena privativa de libertad. Esta interpretación es compatible con la función de la prescripción de la acción penal, cual es extinguir el derecho de persecución penal del Estado ante el delito cometido, y no la extinción de la pena que, como ya se ha mencionado, sólo se produce en función de los plazos a que alude el artículo $86^{\circ}$. Plazos que, por lo demás, recién se contabilizan con posterioridad a la emisión de la sentencia condenatoria correspondiente. Más adelante revisaremos los criterios jurisprudenciales que se han desarrollado sobre todos estos aspectos.

Cuando el autor del delito es funcionario o servidor público (ver artículo $425^{\circ}$ del Código Penal), y se trata de un delito contra el patrimonio del Estado o de organismos sostenidos por éste, los plazos de prescripción ordinaria o extraordinaria se duplican. Son delitos contra el patrimonio del Estado, fundamentalmente, la concusión (arts. 382 a $386^{\circ}$ ) y el peculado (arts. $387^{\circ}$ a $392^{\circ}$ ).

Finalmente, si la infracción penal cometida es una falta, la acción penal prescribe a los seis meses y la ejecución de la pena al año (Art. $440^{\circ}$, Inc. $5^{\circ}$.

\subsection{Inicio de la prescripción}

El artículo $82^{\circ}$ y el artículo $86^{\circ}$, párrafo segundo, señalan el inicio de la prescripción de la acción penal y de la pena, respectivamente.

En cuanto al inicio de la prescripción de la acción penal, la ley toma en cuenta el modo de ejecución y el momento de consumación del delito. La regla general es que el plazo de prescripción de la acción penal debe comenzar a contarse a partir del momento en que el agente concluyó su actividad ejecutiva del delito. Ahora bien, el legislador ha contemplado normas específicas para los casos de tentativa, delito continuado y delito permanente.

Con relación a la tentativa (Art. $16^{\circ}$ C.P.), acabada o inacabada, el plazo de prescripción corre desde que cesa la ejecución imperfecta del hecho punible.

Para el caso del delito continuado (Art. 490 C.P.) la prescripción comienza cuando el agente termine la actividad delictuosa que materializa su única resolución criminal. 
Y en el delito permanente, la cuenta de la prescripción se inicia desde que concluye la situación antijurídica creada y mantenida por el agente.

Un tradicional problema jurisprudencial y doctrinario vinculado a la prescripción, es el que corresponde al cómputo de la acción penal para el delito de usurpación en la modalidad de despojo (Art. 202\%, Inc. 2 C. P.). $\mathrm{Al}$ respecto la discusión siempre ha girado en torno a determinar si dicha infracción penal es un delito instantáneo o permanente. $\mathrm{O}$ si se trata de un delito instantáneo pero de efectos permanentes.

Sobre el particular, debemos mencionar que el verbo típico que gobierna la hipótesis del artículo $202^{\circ}$ inciso 2 es despojar. Esto es, desposeer mediante violencia, amenaza o abuso de confianza al sujeto pasivo de la conducción de un inmueble. Es decir, la acción acontece de modo inmediato y concluye excluyendo a la víctima de la posesión del bien. Y esto último determina la consumación del delito, y, por ende, el inicio de la prescripción. El que el inmueble se mantenga en poder del agente más o menos tiempo constituye un efecto posterior a la consumación, y que ya no implica despojo. La usurpación, pues, en su forma de despojo es un delito instantáneo pero que puede tener efectos permanentes.

Por tanto, consideramos no adecuadas a nuestra legislación la propuesta de interpretación que formulaba Peña Cabrera. ${ }^{59}$ El desaparecido penalista nacional, influenciado por la doctrina española, equiparaba la acción del despojo de carácter instantáneo con la de «ocupar» de claro sentido permanente y que es la que comanda la conducta típica prevista en el artículo $245^{\circ}$ del Código Penal español («al que con violencia o intimidación en las personas ocupare una cosa inmueble o usurpare un derecho real inmobiliaria de ajena pertenencia [...]").

La prescripción de la ejecución de la pena, según lo dispone el artículo $86^{\circ}$ del Código Penal, se inicia en función al hecho procesal de la sentencia firme. Esto es, corre sólo desde que se configura cosa juzgada. El artículo $87^{\circ}$ señala las causales de interrupción en la prescripción de la pena. En primer lugar, señala el hecho de que comience la ejecución de la pena impuesta y en segundo lugar que se detenga al condenado por la comisión de un nuevo delito doloso. Todo parece indicar, en este último supuesto, que es suficiente que la imputación del nuevo delito se encuentre en trámite procesal de investigación o juzgamiento. No es, 
pues, necesario una nueva condena. Se trata, entonces, de una detención preventiva y no del cumplimiento de una nueva pena privativa de libertad. Roy Freyre asume que esta causal sólo podría operar en caso de un delito cometido en el extranjero y en la medida en que exista ya una sentencia condenatoria y una pena impuesta. ${ }^{60}$

\section{5. problemas jurisprudenciales detectados}

No cabe duda que en términos porcentuales la prescripción de la acción penal se constituye en la causal de extinción más común y frecuente en la praxis jurisdiccional. De allí, pues, que las decisiones judiciales en este dominio, pronunciadas fundamentalmente a través de incidentes de excepción (Artículo $5^{\circ}$ del Código de Procedimientos Penales) constituyen un volumen considerable de la casuística que hemos tenido oportunidad de analizar. Sin embargo, pese a la pluralidad de esta clase de resoluciones, los problemas prácticos que se detectan son bastante concretos.

Al parecer, pues, las tendencias y criterios con los que la magistratura evalúa y resuelve la prescripción de la acción penal resultan en lo esencial sumamente homogéneos y estables. Esta constatación resulta interesante si se tiene en cuenta, como ya se precisó, que la regulación de la prescripción en el Código Penal de 1991 (arts. $80^{\circ}$ a $88^{\circ}$ y 91\%) evidenció cambios importantes con relación al marco legal existente en el Código Penal de 1924 (arts. $119^{\circ}$ a $125^{\circ}$ y 129 ${ }^{\circ}$ ). Al respecto, es de recordar que las principales variantes ocurridas determinaron la unificación de los términos de prescripción para las penas privativas de libertad temporales, así como la renunciabilidad de la prescripción de la acción penal por parte del imputado. También se produjeron reformas en lo concerniente a las causales de interrupción, sobre todo como consecuencia de la autonomía funcional que hoy posee para el ejercicio de la acción penal el MinisterioPúblico y por haberse suprimido la reincidencia como status procesal. ${ }^{61}$

59 Cfr. Raúl Peña Cabrera. Tratado de Derecho Penal. Parte Especial II-A. Ediciones Jurídicas. Lima, 1995, p. 512 y ss.

60 Cfr. Luis Eduardo Roy Freyre. Op. cit. p.129.

61 Cfr. Luis Eduardo Roy Freyre. Ibid, p. 53 y ss. 
Examinando, entonces, la evolución práctica del uso de las reglas sobre prescripción de la acción penal se detectan principalmente dos tipos de controversias:

a. La determinación de los plazos de prescripción en caso de delitos sancionados con penas conjuntas.

b. La determinación del cómputo de la prescripción en delitos con penas alternativas.

Seguidamente haremos un detallado estudio de las tendencias jurisprudenciales generadas en el tratamiento y solución de tales problemas. Comencemos ratificando que en la actualidad nuestro Código Penal carece de disposiciones que orienten la decisión judicial del término de la prescripción de la acción penal en caso de delitos que combinan en la sanción conminada, penas privativas de libertad y penas no privativas de libertad como la multa o las penas limitativas de derechos.

El Código sustantivo, por lo demás, posee en su Parte especial un número considerable de estos delitos. Sólo con fines explicativos, podríamos citar como ejemplos a los delitos tipificados en los artículos $110^{\circ}$ (infanticidio), $122^{\circ}$ ab initio (lesiones dolosas leves), 124 ${ }^{\circ}$, (lesiones culposas), $194^{\circ}$ (receptación patrimonial) y $427^{\circ}$ primer párrafo (falsedad en documento público).

En torno a la prescripción de la acción penal en estos supuestos, donde encontramos penas alternativas y conjuntas, se han desarrollado dos criterios judiciales. El primero estima que la prescripción sólo operaría si se han vencido los plazos que corresponden a la pena privativa de la libertad (extremo máximo legal de la pena conminada) y a la pena no privativa de libertad (tres años). Y el segundo, considera que debe declararse la prescripción, únicamente cuando se vence el plazo que corresponde a la pena privativa de la libertad a la cual se califica como la «más grave».

En el Pleno Jurisdiccional de Arequipa - 1997, luego de una enardecida discusión, por mayoría se acordó que la última posición hermenéutica citada debería ser seguida por la judicatura nacional. El acuerdo adoptado fue el siguiente: "Que el término de prescripción de la acción para delitos conminados con penas conjuntas debe fijarse atendiendo al plazo que corresponda al elemento más grave integrado a la 
sanción, que en un caso será la pena privativa de libertad, incluso aunque ésta sea no mayor a dos años» (Acuerdo Plenario No 5-97).

Sin embargo, consideramos esta tendencia equivocada, pues implica una reducción teleológica de la ley penal, lo cual contradice, como el uso de la analogía, el Principio de Legalidad. ${ }^{62}$

En efecto, si estudiamos en detalle el problema planteado, nos encontramos con que él sólo se manifiesta complejo cuando se debate la prescripción en aquellos delitos similares a los previstos en los artículos $114^{\circ}$ (autoaborto) y $122^{\circ}$ (lesiones leves dolosas) del Código Penal. Ya que en ellos el plazo de prescripción referente a la pena conminada no privativa de libertad (tres años) sería superior al que correspondería a la pena privativa de libertad (dos años), surgiendo así la duda sobre la extinción o vigencia de la acción penal.

En otros ilícitos penales, como los tipificados en los numerales $194^{\circ}$ (receptación) y $427^{\circ}$ (falsedad documental), el cómputo de los dos plazos puede observarse sin mayor dificultad, pues en el primer tipo de delitos coincide y en la segunda clase de infracciones se ven comprendidos, sucesivamente, por la mayor extensión de la pena privativa de libertad.

Pues bien, el problema que hemos detectado tiene su origen en una equivocada recepción de la legislación colombiana al momento de decidir la reforma de los plazos de prescripción de la acción penal en delitos sujetos a penas privativas de libertad temporales.

Efectivamente, al decidir el legislador nacional que dicho plazo sería «igual al máximo de la pena fijada por la ley para el delito, si es privativa de libertad», (Art. $80^{\circ}$ ) se limitó a reproducir, de modo parcial, el texto legal del artículo 80 del Código Penal colombiano: «La acción penal prescribirá en un tiempo igual al máximo de la pena fijada en la ley si fuere privativa de libertad, pero, en ningún caso será inferior a cinco años ni excederá de veinte». Lamentablemente el no incorporar en el artículo del Código peruano esta última frase condicional fue determinante y generó el problema que ahora analizamos. El cual, por lo demás, no ocurre en Colombia, ya que la ley atinadamente establece que en "los delitos que tengan señalada otra clase de pena, la acción prescribirá en cinco años».

62 Cfr. José Hurtado Pozo. Manual de Derecho Penal. Parte General. EDDILI. Lima, 1987, p. 196. 
Por consiguiente, pues, si el legislador nacional hubiera señalado en el artículo $80^{\circ}$ que la prescripción de la acción penal en las penas privativas de libertad en ningún caso ocurriría antes de los tres años de cometido el delito, no se producirían conflictos aparentes como el planteado en torno al artículo $122^{\circ}$. Por tanto, el error del legislador no puede afectar el sentido de proporcionalidad que subyace en la prescripción cuando se trata de penas conjuntas. Esto es, si son dos los plazos a tener en cuenta en el cómputo y evaluación de la prescripción, por tratarse de dos penas diferentes, lo adecuado y justo es que también se deban verificar ambos plazos para decir la extinción de la acción penal. Además, la legislación sustantiva sólo autoriza tener en cuenta el plazo que corresponde a la pena más grave en caso de un concurso ideal de delitos (Cfr. Art. $80^{\circ}$ tercer párrafo), ya que tratándose de un concurso real «las acciones prescriben por separado» (Cfr. Art. $80^{\circ}$ segundo párrafo).

De otro lado, el error de apreciación del sector mayoritario en el Pleno jurisdiccional de Arequipa - 1997 se manifiesta con mayor nitidez en el contenido de las consideraciones cuarta y quinta del referido acuerdo plenario:

«Cuarta: Que por su propia naturaleza, las penas conjuntas deben necesariamente ser aplicables a la vez, lo que se desprende del uso que en ellas se hace de la conjunción ' $y$ '.

Quinta: Que en caso de que uno de los elementos que integran la pena conjunta haya prescrito, la aplicación simultánea de ambas deviene en jurídicamente imposible».

Como se puede observar, estas consideraciones no sólo son implicantes sino que en el caso de la "quinta» confunde la prescripción de la ejecución de la pena con la prescripción de la acción penal. La pena no prescribe porque se venza uno de los plazos de prescripción necesarios para la extinción de la acción penal en delitos con sanciones conjuntas. Fundamentalmente porque lo que se está evaluando o discutiendo con dichos plazos no es la pena a imponer en la sentencia sino el derecho mismo del Estado a perseguir y procesar al autor de un delito. Las penas sólo prescriben luego de haber sido impuestas; por tanto, mientras el Estado esté facultado para perseguir un delito podrá 
el órgano jurisdiccional al sentenciar, aplicar todas las penas previstas en la ley para el hecho sub judice.

Más aún, lo incoherente en el acuerdo plenario que se está comentando se pone de relieve también cuando en las consideraciones novena y décima se trata de la prescripción en caso de penas alternativas, en la que, curiosamente, no se concede preeminencia a la pena privativa de libertad para el cómputo de la prescripción, ni se imposibilita al Juez a considerar en la sentencia sólo la pena cuyo plazo no se hubiera vencido al momento de sentenciar:

«Novena: Que en el caso de delitos conminados con penas alternativas corresponderá al juzgado establecer, al momento de imponer la condena, cuál de las penas posibles corresponde a la responsabilidad del agente.

Décima: Que, en concurrencia, en el caso de penas alternativas, es imperativo considerar prescrita la acción penal sólo cuando ninguna de las penas conminadas posibles sea susceptible de imposición».

El texto de la Resolución Plenaria en este dominio no es menos sorprendente ya que contradice totalmente al adoptado sobre penas conjuntas: "Que en el caso de delitos conminados con penas alternativas, la acción penal sólo debe considerarse prescrita cuando se haya cumplido el plazo más largo que resulte de las penas susceptibles de imposición».

Un ejemplo nos puede graficar los despropósitos a que nos llevaría aplicar los acuerdos adoptados. Para ello utilizaremos el artículo $124^{\circ}$ del Código Penal sobre lesiones culposas pero en su redacción original y contemporánea a la fecha de realización del Pleno 97, esto es, antes de la Ley No 27054. El citado artículo, en su primer párrafo, consideraba para las lesiones culposas leves, penas alternativas, y para las lesiones culposas graves, en su segundo párrafo, penas conjuntas. Pues bien, aplicando los acuerdos del Pleno de Arequipa tendríamos los siguientes resultados:

a. El delito de lesiones leves, por tener penas alternativas y a pesar de ser un ilícito menos grave, prescribiría ordinariamente a los tres años, y extraordinariamente a los cuatro años y seis meses, pues su "plazo 
más largo» es aquél que deriva de la pena de multa (sesenta a ciento veinte días-multa).

b. El delito de lesiones graves sancionable con penas conjuntas y perseguible de oficio por implicar una mayor afectación de la salud del sujeto pasivo, prescribiría ordinariamente a los dos años y extraordinariamente a los tres años, pues esos serían los límites generados por la pena privativa de libertad (no mayor de dos ańos).

De allí, pues, que por tales incongruencias y desproporciones el Acuerdo plenario de Arequipa sobre prescripción de la acción penal en delitos con penas conjuntas o alternativas no se viene acatando en el presente.

En línea de conclusión, entonces, sostenemos que tanto en penas conjuntas como en penas alternativas, la prescripción de la acción penal sólo puede ser declarada si en el caso concreto se han vencido todos los plazos que correspondan a las penas conminadas en la ley. ${ }^{63}$

En las ejecutorias superiores de fecha 29 de mayo de 1998 (Expediente $N^{\circ}$ 250-94, procedente de la Primera Sala Penal Corporativa para Procesos Ordinarios con Reos Libres de Lima) y 31 de julio de 1998 (Expediente N 450-98, procedente de la Sala Especializada en lo Penal del Cono Norte de Lima), correspondientes a dos distritos judiciales diferentes, el criterio que hemos asumido como correcto ha sido también adoptado por ambas decisiones jurisdiccionales. Así, por ejemplo, en la primera de estas resoluciones se argumenta lo siguiente: «a que conforme trasciende de la acusación fiscal de fojas ciento dieciocho y ciento diecinueve, así como del auto superior de enjuiciamiento de fojas ciento veinte, el Colegiado declaró Haber Mérito para pasar a juicio Oral contra Gilberto Palomino Mendoza por los delitos contra la Vida, el Cuerpo y la Salud- Homicidio culposo- y contra la Función Jurisdiccional, ello en aplicación de lo dispuesto en los artículos ciento once y cuatrocientos ocho del Código Penal, que prescribe una pena privativa de libertad en el primer caso, no mayor de dos años o con prestación de servicio comunitario de cincuentidós a ciento cuatro jornadas y en el segundo una pena privativa de la libertad de tres años y con noventa a ciento veinte días-multa; que tratándose de penas conminadas alternativamente la prescripción opera si ha vencido para-

63 Cfr. Víctor Prado Saldarriaga. Todo sobre el Código Penal. Op. cit., p. 150 y 151. 
lelamente o secuencialmente los diferentes plazos de prescripción que corresponden a todas las penas alternativas o conjuntas; por lo que siendo ello así, en estricta aplicación del numeral ochenta, concordante con el artículo ochentitrés del Código sustantivo antes invocado, el término de prescripción en el caso concreto resulta ser de cuatro años y seis meses, al existir una pena diferente a la pena privativa de la liber$\operatorname{tad}[\ldots] »$.

La segunda ejecutoria citada, con convicción y detalle, precisa que «la extinción de la acción penal por prescripción es viable únicamente cuando han vencido paralelamente o de manera extrema todos los diferentes plazos que establece la norma legal antes glosada referida a todas las penas alternativas o conjuntas previstas, por lo que resulta errado atender a los plazos de prescripción únicamente basados en los límites de la pena privativa de la libertad, puesto que ellas constituyen sólo un sistema de los varios que acoge el sistema normativo penal por lo que su condición punitiva es igual con la diferencia del bien jurídico que restringe; Que, por otro lado, un delito sancionado con pena privativa de la libertad y otra conjunta o alterna, aún cuando habría prescrito en razón de la pena privativa de la libertad si por consideración de la otra pena no ha prescrito, faculta la imposición inclusive de la pena privativa de la libertad, por cuanto la institución de la prescripción no está referida a la extinción de la pena, sino tiene el atributo de concluir el derecho de persecución penal del Estado ante el delito cometido a través de la extinción de la acción penal [...]».

Sin embargo, en la Ejecutoria Suprema del 30 de abril de 1997 (Expediente $\mathrm{N}^{\circ}$ 2550-96, procedente de Ancash) se da prioridad a la prescripción de acción penal en delitos con penas alternativas o conjuntas, evaluando solamente el plazo aplicable a la pena privativa de libertad, decisión que se adopta con una argumentación poco comprensible y que se expresa en los siguientes términos: «que de la revisión del proceso se advierte que los delitos contra la Vida, el Cuerpo y la Salud-lesiones leves- y contra la Libertad Personal -coacción- imputados a los acusados [...] ocurrieron en el mes de enero de mil novecientos noventidós, los mismos que se encuentran previstos en el artículo ciento veintidós del Código Penal vigente, reprimido simultáneamente con pena privativa de la libertad no mayor de dos años y multa y en artículo ciento cincuentiuno del mencionado dispositivo legal, con pena privativa de la libertad no mayor de dos años; que, la 
regla contenida en el último parágrafo del artículo ochenta del Código Penal está referida a los delitos que merezcan otras penas distintas a la privativa de libertad, mas no a las penas complementarias que se impongan conjuntamente con ésta; que por ello teniendo en cuenta lo dispuesto por los artículos ochenta y ochentitrés del Código Penal acotado, desde la realización del evento delictivo a la fecha ha transcurrido el plazo previsto para que opere la prescripción [...]». Al parecer, pues, para esta decisión del Supremo Tribunal el párrafo in fine del artículo $80^{\circ}$ del Código Sustantivo sólo operaría en delitos donde la pena conminada como única sanción sea una pena no privativa de libertad. Este razonamiento, a nuestro modesto entender, estaría limitando los alcances del texto legal y no podría resolver situaciones como la presencia de penas alternativas.

Como habíamos advertido, otras normas sobre la prescripción han sido aplicadas con criterios adecuados y uniformes. Por ejemplo, la Ejecutoria Suprema de fecha 12 de febrero de 1997 (Expediente No 1624-96, procedente de Lima) aplicando el artículo $81^{\circ}$ del Código Penal, reduce los plazos de prescripción a la mitad, ya que «al momento de comisión del delito sub-judice el procesado contaba con más de sesenticinco años de edad".

Por su parte, la Ejecutoria Suprema de fecha 13 de enero de 1997 (Expediente No 2854-95-B, procedente de Lima) al resolver la prescripción en un concurso ideal de delitos ciñéndose a lo previsto en el párrafo tercero del artículo $80^{\circ}$ del texto sustantivo, consideró que «la acción penal aún no ha prescrito por cuanto no ha transcurrido el plazo correspondiente al delito más grave».

En las Ejecutorias Superiores de fecha 01 de julio de 1998 (Expediente $N^{0}$ 1202-98, procedente de la Sala Penal de Apelaciones para Procesos Sumarios con Reos Libres de Lima) y de fecha 20 de mayo de 1996 (Expediente No 332-95, procedente de la Décimo Segunda Sala Penal de Lima), se reproduce la inveterada discusión sobre la condición instantánea o permanente de ciertos delitos como la desobediencia a la autoridad (Art. $168^{\circ}$ ) o la omisión de asistencia familiar (Art. 149 ${ }^{\circ}$ ). Este debate de la jurisprudencia nacional encuentra un espacio singular en cuanto incide en torno al delito de usurpación de inmuebles en su modalidad de despojo (Art. $202^{\circ}$ Inc. $2^{\circ}$ ). A pesar del tiempo que lleva de vigencia el Código Penal de 1991 y a los esclarecedores conceptos expuestos por la doctrina nacional todavía subsisten resoluciones judi- 
ciales que persisten en considerar a dicho ilícito como de naturaleza permanente. $^{64}$

Ahora bien, en la segunda de las ejecutorias superiores citadas, el órgano jurisdiccional procura alcanzar una distinción entre delitos permanentes y los llamados delitos instantáneos de efectos permanentes: «a que conforme a la doctrina, se denomina delito de comisión permanente a aquél en el cual el estado de antijuricidad no cesa y persiste por actos posteriores del agente; que, en el caso de autos nos encontramos frente a delitos de consumación instantánea, siendo sólo sus efectos los que se proyectan en el tiempo [...]».

Resulta interesante el contenido de las Ejecutorias: Suprema de fecha 11 de noviembre de 1996 (Expediente No 1980-95, procedente de Lima) y Superior de fecha 25 de marzo de 1997 (Expediente No 6095, procedente de la Primera Sala Penal de Lima) en tanto que ratifican la utilidad de la llamada prescripción extraordinaria o «larga»; asimismo, dejan entrever que los plazos de este tipo de prescripción se deben computar considerando también el tiempo acumulado en segunda instancia.

Finalmente, en la Ejecutoria Suprema de fecha 20 de noviembre de 1998 (Expediente No 2476-98, procedente de Lima) se advierte una reevaluación del principio de combinación y de sus efectos en torno a las reglas especiales de prescripción para delitos cometidos por funcionarios públicos y que afectan el patrimonio del Estado. Según la decisión que comentamos no es posible considerar sólo parcialmente las normas de una ley vigente al momento de comisión del delito y combinarla con normas originales del Código Penal de 1991. Esta interpretación que se basa en la ilegalidad de la llamada lex tertia, como lo reconoce la propia resolución en análisis, limita la actitud jurisprudencial asumida con anterioridad por nuestro Supremo Tribunal. Según la Primera Sala Penal Transitoria de la Corte Suprema: «no es del caso invocar, como lo hace el Colegiado, en el caso de la prescripción, la aplicación de la legislación penal anterior inaplicando un supuesto normativo de la misma, bajo el argumento que el Código sustantivo actual no lo contempla, pues en este caso no se trata de una institución

64 Cfr. Luis Alberto Bramont-Arias Torres - María del Carmen García Cantizano. Manual de Derecho Penal. Parte Especial. Tercera Edición. Editorial San Marcos. Lima, 1997, p. 377. 
jurídica regulada en forma homogénea; por lo que debe aplicarse el segundo párrafo del artículo ciento diecinueve del Código Penal de mil novecientos veinticuatro, modificado por el Decreto Legislativo número ciento veintiuno que establece que el plazo de la prescripción se aumentaría en una mitad cuando se trate de delitos cometidos en agravio del Estado [...] que, en este orden de ideas, si bien este Supremo Tribunal en reiterada jurisprudencia ha establecido la posibilidad de aplicar el principio de combinación conforme al artículo sexto del Código Penal de mil novecientos noventiuno; sin embargo, en atención a la facultad conferida por el artículo veintidós del Texto Único Ordenado de la Ley Orgánica del Poder Judicial, es del caso precisar que dicho principio no se puede aplicar irrestrictamente, sino que debe respetar la coherencia normativa de las instituciones en comparación, a fin de evitar su desnaturalización y la creación judicial de una tercera norma, lo que es incompatible con nuestro sistema constitucional [...]».65

65 Cfr. Luis Alberto Bramont-Arias Torres - María del Carmen García Cantizano. Manual de Derecho Penal. Parte Especial. Tercera Edición. Editorial San Marcos. Lima, 1997, p. 377. 